\title{
Predicting mortality for even-aged stands of lodgepole pine
}

$A$ method is described for the prediction of future mortality of lodgepole pine (Pinus contorta Dougl.) for the estimation of net growth in planning of a timber management system. Data from British Columbia and Alberta lodgepole pine yield tables were applied to calculate regressions which estimate mortality. Comparisons between the actual and predicted mortality over a 5-year period for 2 sets of permanent sample plot data demonstrate that the method (with mean dbh as predictor) can be used with confidence for estimating future mortality. Percentage distribution of dead trees by dbh class is found to be approximately normal. Number of dead trees for each dbh class can be estimated using a normal distribution. An example shows the method for determining the number of expected dead trees, by dbh classes, for a 5-year period.

Mortality is one of the most important variables for predicting stand growth, an essential in any timber management system. Yet mortality in any species is extremely variable, and difficult to predict. There are two types of mortality, regular and irregular. Regular mortality is found when trees grow so close together that they must compete for survival. Such competition for a limited supply of light, moisture and nutrients is most intensive in overstocked stands, and non-existent in fully open-growth trees. The crowded, overtopped and suppressed trees eventually die. The vigorous trees and those adapted to the environment are likely to survive. This probability of survival increases with size and age until the tree is mature. On the other hand, mortality caused by insect, disease, windfall, fire or snow damage is termed "irregular mortality". The rate of irregular mortality is either high or low for short periods and is very difficult to predict. Current mortality, based on observations over a relatively short period and on a limited number of plots, is often of little value in estimating future mortality. Only the aggregate information gathered from a series of observations based on permanent sample plots can be used with any degree of confidence for predicting future mortality (Society of American Foresters 1955). Hence, reliable sources of information on mortality are based on either a large number of permanent sample plots or yield tables (Krauch 1930, Deen 1933, Spurr 1952, and Staebler 1953).

Lodgepole pine (Pinus contorta Dougl.) is one of the leading softwoods in supplying raw material for the pulp and paper industry in Western Canada. Stands of lodgepole pine occupy a large portion of the forested area in western Alberta (Alberta Forest Service 1961) and the interior of British Columbia (British Columbia Forest Service 1957). Intensive timber management for this species calls for accurate growth estimation, which in turn calls for accurate prediction of future mortality of lodgepole pine.
In this article, mortality for even-aged stands of lodgepole pine is predicted through the use of regression analysis from existing yield tables, with

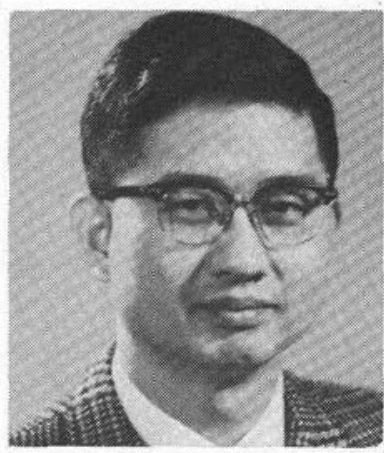

Y. (JIM) LEE

Conadian Forestry Service Forest Research Laboratory 506 West Burnside Road Victoria, B.C.

dead tree tallies from re-measurements of permanent sample plots as a check. An example is included to illustrate how the method can be applied in predicting mortality.

\section{Methods}

The method was devised by the author while completing a Ph.D. program at the University of British Columbia (Lee 1967).

The following modified discount formula has been used to calculate the rate of mortality: where

$$
\mathrm{MR}=100[1-\sqrt[n]{(\mathrm{FNT}) /(\mathrm{BNT})}]
$$

$($ FNT $)=$ Final number of trees per acre at the end of the period.

$(B N T)=$ Number of trees per acre at the beginning of the period.

$\mathrm{n} \quad=$ Number of years for the period (5 years in this case).

$\mathrm{MR}=$ Annual mortality rate (\%).

This formula, together with data from yield tables, can be used to calculate the mortality rate, which can then be related to stand parameters.

In this paper, the formula is applied to lodgepole pine yield tables developed in Alberta by Smithers (1961) and in British Columbia by the British Columbia Forest Service (1936). The mortality rates are plotted against the corresponding age and mean dbh. The plottings appear to follow the following regression models:

$$
\begin{aligned}
\log Y & =a+b X \\
Y & =a+b X \\
Y & =a+b X+c X^{2} \\
Y & =a+b(1 / X)
\end{aligned}
$$

Regression analyses of MR on age or mean $\mathrm{dbh}$ have been made separately, using the above models. The best regressions for the estimate of mortality rate are as follows: 
1/ Alberta yield tables:

$\mathrm{MR}=5.3012-0.07438($ Age $)+0.000312$ (Age $)^{2}$

Number of observations $=140, R=0.822^{* *}$, $\mathrm{R}^{2}=0.676, \mathrm{SE}_{\mathrm{E}}=0.64 \%$

2/ British Columbia yield tables:

$\mathrm{MR}=-0.3203+91.7757 /($ Age $)$

Number of observations $=66, \mathrm{R}=0.987^{* *}$, $\mathrm{R}^{2}=0.974, \mathrm{SE}_{\mathrm{E}}=0.08 \%$

3/ Alberta yield tables:

$M R=4.252-0.801(D)+0.04752(D)^{2}$

Number of observations $=140, R=0.648 * *$, $\mathrm{R}^{2}=0.420, \mathrm{SE}_{\mathrm{E}}=0.86 \%$

4/ British Columbia yield tables:

$\mathrm{MR}=3.815-0.640(D)+0.03051(D)^{2}$

Number of observations $=66, \mathrm{R}=0.758^{* *}$, $\mathrm{R}^{2}=0.574, \mathrm{SE}_{\mathrm{E}}=0.34 \%$

\section{Analysis of 2 sets of permanent sample plot data}

Information on actual mortality has been obtained from permanent sample plots established by the Alberta Forest Service (Edmonton data) and the Canadian Forestry Service (Calgary data).

Edmonton data. One hundred and forty-four permanent sample plots of fully stocked lodgepole pine were established by the author from 1960 to 1962 and re-measured in 1968. One hundred of these plots were located within 100 miles of Whitecourt, and the other 44 plots within 100 miles of Rocky Mountain House, Alberta. The stand ranges in age from 61 to 177 years old with an average age of 82 years; and ranges in basal area per acre from 79.5 to 251.5 square feet, with an average of 155.2 square feet. All trees within each plot were numbered and tagged. All 144 plots were found suitable for the analysis. No ingrowth was found for any of these 144 plots. Predicted mortality was determined for each plot, using regressions 1, 2, 3 and 4 .

A test using paired differences (Snedecor 1956, p.49) was employed to evaluate the differences between the actual and predicted mortality over a 5 -year period.

Non-parametric tests were run without the assumptions of normality and homogeneity of variance, which validated the results of all the paired t-tests.

Significant differences were found to exist between actual and predicted mortality when age is used as predictor ( $t$ value is 8.314 for regression 1 and 5.269 for regression 2). However, no significant differences exist when mean dbh is used ( $t$ value is 1.314 for regression 3 and 1.746 for regression 4 ).

Calgary data. One hundred and three permanent sample plots of lodgepole pine established in 1951, 1952 and 1953 in the Foothills Section of Alberta were remeasured in 1961. Individual trees within each plot were not tagged. Actual mortality was obtained by subtracting the total number of trees tallied in 1961 from that of 1951, 1952 or 1953. Whenever the resultant figure was negative, the plots were rejected. Since no ingrowth was found for any of the Edmonton data, it is reasonable to assume that no significant amount of ingrowth is encountered in Calgary data during the brief period between the two tallies. The negative mortality is probably due to error in tallying and not to ingrowth. A total of 96 plots were found suitable.

Of these 96 plots, 47 were located within 100 miles of Hinton, and the remaining 49 plots within 100 miles of Rocky Mountain House in west central Alberta. The stand ranges in age from 30 to 183 years old with an average of 76 years. Basal area per acre ranges from a low of 58.1 to a high of 219.2 with an average of 140.7 square feet. These plots are considered to be fully stocked lodgepole pine stands.

Mean dbh was calculated and MR determined through the use of regressions 1 and 3 for the Alberta yield tables, and 2 and 4 for the British Columbia yield tables. Means of paired samples t-tests between actual and predicted mortality over a 5 year period were conducted. No significant differences between actual and predicted mortality were found for regressions 1 ( $t$ value: 1.326 ) and regression 3 (t value: 2.606 ) at the $5 \%$ level, but significant differences were found for regressions 2 ( $\mathrm{t}$ value: 4.665 ) and regression 4 ( $\mathrm{t}$ value: 3.180 )

According to the foregoing analysis, the stand parameter, mean $\mathrm{dbh}$, is better than age for predicting future mortality, especially for the regression derived from Alberta yield tables.

\section{Distribution of dead trees by dbh class}

It is well known that regular mortality usually occurs in smaller dbh classes in the stand, but there is limited published information on this subject. Smith et al. (1965) stressed the importance of distribution and amount of mortality as defined by simulation studies. Observations in Russia, published by Eytingen in 1949, showed that regular mortality in natural stands occurred commonly among trees with dbh less than the mean dbh (Czarnowski 1961).

Using the 144 Alberta Forest Service plots, the author calculated the percentage dbh distributions of dead trees by stand mean dbh (Figure 1). Ninety per cent or more of dead trees fall into the dbh classes including and below the stand mean $\mathrm{dbh}$ in stands with a mean dbh of 3 to 8 inches. For stands with mean dbh of 9,10 and 11 inches, 73 to $85 \%$ fall into the dbh classes including and below the mean $\mathrm{dbh}$.

Fitting the observed dbh distribution of dead trees with that of the standard distributions

Analyses were carried out to fit the observed frequency distributions with the normal distribution (Freund 1962, p.285). This was done in terms of percentage of all dead trees by dbh class for stands having mean dbh 3 to 11 inches. The distributions were normal for trees in the 4- to 9-inch dbh classes with the exception of the 5 -inch class where the 
difference was significant at the $5 \%$ level. Other mean dbh classes differ, but this was probably due to insufficient plots. The binomial, Poisson and negative binomial distributions were also fitted but proved to be unsuitable.

From the results of these tests, it can be concluded that the percentage of dead trees in each dbh class is normally distributed among the dbh classes, with the mean at approximately 2 inches below the mean dbh (Fig. 1). The number of dead trees for each dbh class can be assigned according to normally distributed probabilities. The relationship between standard deviation of $\mathrm{dbh}$ of dead trees and stand mean dbh for Edmonton data was determined and shown in Figure 2. A free hand curve as well as a best regression line was plotted superimposed on the original data. The best regression was found to be:

$($ Standard Deviation $)=0.4166+0.02571$ (Stand mean dbh) ${ }^{2}$

$\mathrm{N}=9, \mathrm{R}=0.992^{* *}, \mathrm{R}^{2}=0.984, \mathrm{SE}_{\mathrm{E}}=0.97 \%$ However, the free hand curve appears to be better fitted than the regression line (Figure 2).

It is obvious that the variability of dbh of dead trees for each one-inch stand mean dbh increases as stand mean dbh increases. This is due to the fact that the number of dead trees decreases as stand mean dbh increases, while the range in dbh of dead trees increases as stand mean dbh increases.

\section{Application}

Mortality is generally associated with high variances, which in turn make the prediction rather complex. The above procedure devised for the prediction of future mortality of even-aged lodgepole

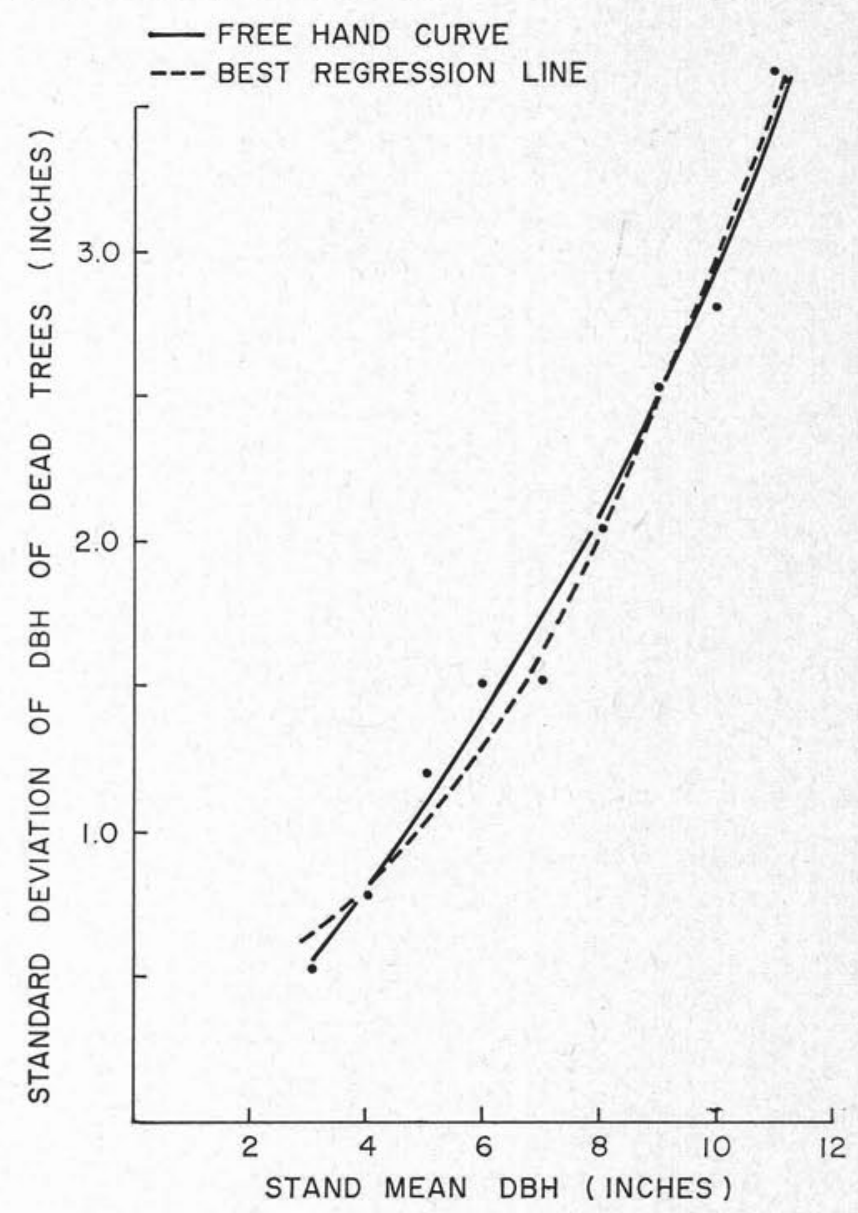

Fig. 2. The relationship between standard deviation of $\mathrm{dbh}$ of dead trees and stand mean dbh.

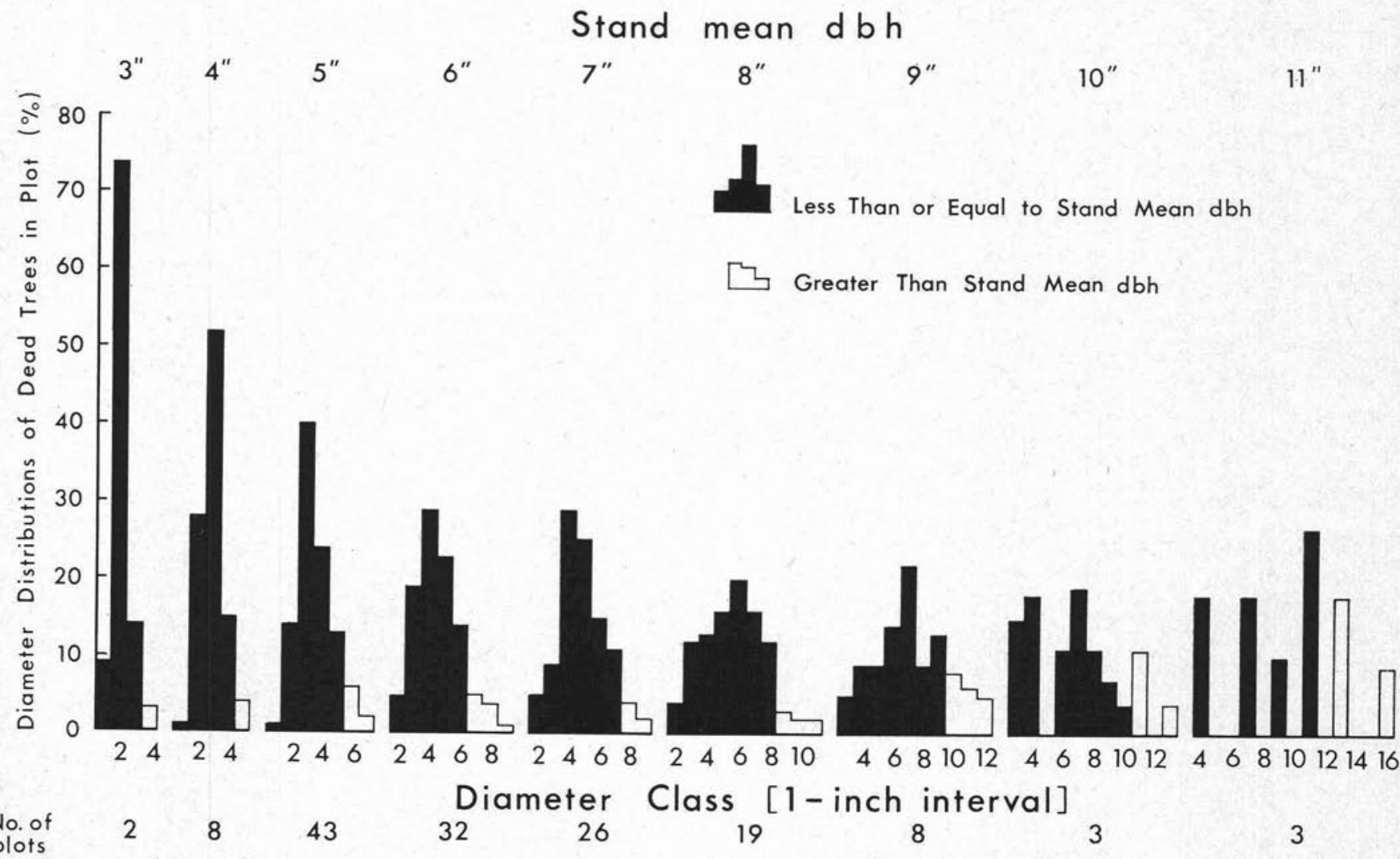

Fig. 1. Percentage diameter distributions of dead trees in plot by mean duh. 
is based on Alberta and British Columbia yield tables, respectively; hence, application of the method is perhaps limited to these provinces. Furthermore, the accuracy of the method is also a function of the accuracy of the yield tables used.

The following example illustrates how the method can be applied in predicting the number of trees (by dbh classes) that may be expected to die within the next 5 years in a 10-acre tract of timber.

Example: Area $=10$ acres; mean dbh $=6.4$ inches; number of trees per acre $=810$; number of trees for the 10-acre tract $=8100$; mean $=6.4-2.0$ $=4.4$ inches; $M R=1.648$ (Regression 3$)$; MR $=1.588$ (Regression 4).

Number of trees dying in a 5-year period for the 10-acre tract:

$10 \times 5 \times 810 \times 1.648 / 100=667$ trees $(\mathrm{Al}-$ berta)

$10 \times 5 \times 810 \times 1.588 / 100=643$ trees (B.C.)

\begin{tabular}{|c|c|c|c|c|c|}
\hline \multirow[b]{2}{*}{$\begin{array}{l}\text { Dbh class } \\
\text { (inches) }\end{array}$} & \multirow{2}{*}{\multicolumn{2}{|c|}{$\begin{array}{c}\text { Range } \\
\text { (inches) }\end{array}$}} & \multirow[b]{2}{*}{$\underset{\%^{1}}{\text { Probabilities }}$} & \multicolumn{2}{|c|}{$\begin{array}{l}\text { Number of expected } \\
\text { dead trees }\end{array}$} \\
\hline & & & & Alberta & $\begin{array}{c}\text { British } \\
\text { Columbia }\end{array}$ \\
\hline $\begin{array}{l}1 \\
2 \\
3 \\
4 \\
5 \\
6 \\
7 \\
8\end{array}$ & $\begin{array}{l}1.5 \\
2.6 \\
3.6 \\
4.6 \\
5.6 \\
6.6\end{array}$ & $\begin{array}{ll}= & 2.5 \\
= & 3.5 \\
= & 4.5 \\
- & 5.5 \\
- & 6.5 \\
- & 7.6\end{array}$ & $\begin{array}{r}3.1 \\
8.1 \\
17.0 \\
24.4 \\
23.8 \\
15.1 \\
6.6 \\
1.9\end{array}$ & $\begin{array}{r}20 \\
54 \\
113 \\
163 \\
159 \\
101 \\
44 \\
13\end{array}$ & $\begin{array}{r}20 \\
52 \\
109 \\
157 \\
153 \\
97 \\
43 \\
12\end{array}$ \\
\hline & & Total & 100.0 & 667 & 643 \\
\hline
\end{tabular}

${ }^{1}$ Stand mean $\mathrm{dbh}=6.4$ inches; standard deviation $=1.55$ inches

\section{Discussion and conclusions}

Predicted mortality for Calgary and Edmonton data through the use of regressions 3 and 4 do not differ significantly from the actual mortality for a 5 -year period. The stand parameter, mean dbh, can be utilized with confidence in predicting future mortality for a tract of timber; age, however, is less reliable.

Among the stand parameters, mean $\mathrm{dbh}$ is the nearest combined expression of site, age and density of a stand. Age is not a good predictor as it indicates neither site quality nor stand density.

Intensive management calls for good growth estimation, which requires accurate prediction of expected mortality. In addition, the amount of expected mortality so determined can be salvaged as

\section{Literature cited}

ALBERTA FOREST SERVICE. 1961. Alberta forest inventory. Forest Surveys Branch, Dep. Lands \& Forests, Edmonton, Alberta. 40 p.

BRITISH COLUMBIA FOREST SERVICE. 1936. Volume, yield, and stand tables for some of the principal timber species of British Columbia. Res. Div. B.C. Forest. Serv., Victoria, B.C. 53 p.

BRITISH COLUMBIA FOREST SERVICE. 1957. Continuous forest inventory of British Columbia, initial phase. 1957. Surv. Inventory Div., B.C. Forest. Serv. Victoria, B.C.

CZARNOWSKI, M. S. 1961. Dynamics of even-aged forest stands. Louisiana State Univ. Biol. Sci. Ser. 4. 132 p.

DEEN, J. L. 1933. A survival table for even-aged stands of northern white pine. J. Forest. 31: 42-44.

FREUND, J. E. 1962. Mathematical statistics. Prentice-Hall, Inc. Engelman Cliffs, N.J. 390 p. thinning (Worthington 1955), if this is economically possible before mortality actually occurs.

The method discussed is best applied to a large area. Application of the method to a small area, e.g., less than 5 acres, is less accurate. This is due to the fact that the original relationship between MR and mean $\mathrm{dbh}$ was derived from the yield table as a whole. In other words, the relationship represents the average value for a large tract of timber.

\section{Acknowledgments}

Gratitude is extended to Mr. R. F. Ackerman of the Canadian Forestry Service, Calgary, Alberta and to Mr. J. F. Hogan of the Alberta Forest Service, Edmonton, Alberta, for their kindness in supplying lodgepole pine data. The paper was reviewed by Dr. J. H. G. Smith, Professor of Forestry, University of British Columbia. His comments are appreciated and were useful to the author.

\section{Prévision du taux de mortalité des peuplements équiennes de pin à feuilles tordues}

II s'agit d'une méthode servant à prédire le taux de mortalité du pin à feuilles tordues (Pinus contorta Dougl.) dans le but de connaître la croissance nette nécessaire à la planification du plan d'aménagement. Les données des tables de rendement de la Colombie-Britannique et de l'Alberta pour le pin à feuilles tordues ont été utilisées dans le calcul de régression du dit taux. Comparant, au moyen de deux groupes de places-échantillons permanentes, le taux réel de mortalité avec celui estimé pour une période de cinq ans, l'auteur conclut que sa méthode - utilisant comme critère le diamètre moyen à la hauteur de poitrine ( $\mathrm{dhp})$ - peut être utilisée avec assurance dans l'estimation de ce taux.

La distribution des pourcentages d'arbres morts par classe de diamètre s'avérait à peu près normale, de sorte que le nombre d'individus morts pour chaque classe de diamètre peut être évalué par l'emploi d'une courbe de distribution normale. L'auteur cite un exemple permettant de connaître sur une période de cinq ans la quantité d'arbres ainsi condamnés, par classe de diamètre.

KRAUCH, H. 1930. Mortality in cut-over stands of western yellow pine. J. Forest. 28: 1085-1097.

LEE, Y. 1967. Stand models for lodgepole pine and limits to their application. Fac. Forest., Univ. B.C., Ph.D. thesis 332 p. Litho.

SMITH, J. H. G., R. M. NEWNHAM and J. HEJJAS. 1965. Importance of distribution and amount of mortality can be defined by simulation studies. Common. Forest. Rev. 44(3): 188-192.

SMITHERS, L. A. 1961. Lodgepole pine in Alberta. Can. Dep. Forest., Bull. 127. 153 p.

SNEDECOR, G. W. 1956. Statistical method. The lowa State College Press, Ames, lowa. 534 p.

SOCIETY OF AMERICAN FORESTERS. 1955. Forestry handbook. The Ronald Press Co., N.Y. 1139 p.

SPURR, S. H. 1952. Forest inventory. The Ronald Press Co. N.Y. 476 p.

STAEBLER, G. R. 1953. Mortality estimation in fully-stocked stands of young-growth Douglas fir. U.S. Forest. Serv. P.N.W. Forest. Range. Exp. Sta., Res. Pap. 4. 8p.

WORTHINGTON, N. P. 1955. Mortality can be salvaged. Rep. from Lumberman, April 1955. 4 p. 